\title{
Micro Efficiency and AgGregate Growth In ChILE*
}

\author{
RAPHAEl BERGOEING \\ Universidad de Chile \\ ANDREA REPETTO \\ Universidad de Chile
}

\begin{abstract}
Using plant-level data on Chilean manufacturing firms for the 1980-2001 period, we estimate and characterize disaggregate total factor productivity. We use these estimates to study the microeconomic sources of aggregate efficiency, a fundamental part of aggregate growth. By decomposing productivity dynamics into production reallocation and within plant efficiency changes, we find that reallocation accounted for almost all of total efficiency gains in Chile during the past few decades. The entry of new, more productive units explains most of these reallocation gains. Within-plant productivity growth contributes positively only during the 1990s, due perhaps to a lag between the implementation of major market oriented structural reforms -mostly undertaken during the late 1970s and early 1980s- and their complete effect on the economy. Our findings suggest that once reforms were consolidated, unbounded within-plant efficiency gains driven by technology adoption and innovation occurred.
\end{abstract}

JEL: L16, L60, O30, O47

Keywords: Plant Dynamics, Total Factor Productivity, Growth, Chilean Manufacturing.

\section{INTRODUCTION}

The growth of output is mostly accounted for by the dynamics of aggregate efficiency. Chilean GDP per working-age person and aggregate total factor

\footnotetext{
${ }^{*}$ We thank the Instituto Nacional de Estadísticas for providing the manufacturing plant-level data used in this paper. We also thank the research assistance provided by Rafael Labarca. We acknowledge financial support from the IADB, Fondecyt \# 1050499, and an institutional grant to CEA from the Hewlett Foundation. Useful comments and suggestions have been provided by two anonymous referees and by participants in several seminars and conferences, especially John Haltiwanger, Alejandro Micco, Klaus Schmidt-Hebbel, and Raimundo Soto.

E-mails: raphaelb@dii.uchile.cl, arepetto@dii.uchile.cl
} 
productivity (TFP) display high-comovement since 1960 (Figure 1). ${ }^{1}$ The evidence for other developed and developing economies, reported by Kehoe and Prescott (2002) and Solimano and Soto (2006) respectively, is similar. This positive correlation between output and productivity growth is stronger the longer is the time period considered. Thus, to understand aggregate growth, we must first understand aggregate efficiency. ${ }^{2}$

FIGURE 1

GDP PER WORKING-AGE PERSON AND TFP

$($ Index $1960=100)$

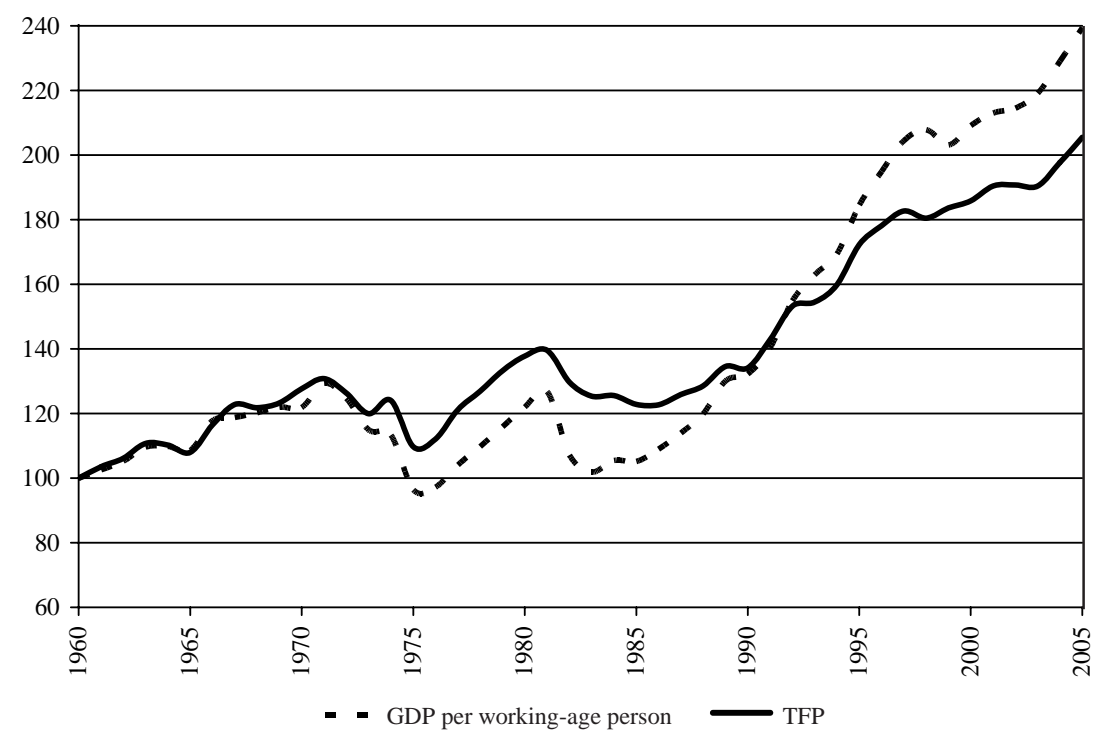

Source: Authors' calculations.

Two sources of productivity gains drive aggregate efficiency over time: the exposure of economic units to better methods of production (within-plant efficiency gains), and the Schumpeterian creative destruction process through which efficient firms thrive while inefficient ones disappear (reallocation driven efficiency gains). The former results from the adoption of new and better technologies and the implementation of more efficient production processes; the latter, from the reshuffling of resources from less to more productive firms and the entry and exit process. A number of papers report evidence for developed

${ }^{1}$ TFP is calculated assuming a Cobb-Douglas production function and a share of capital of 0.35 . We multiply employment by average working hours according to Instituto Nacional de Estadísticas. We use capital series from Ministerio de Hacienda (2004), updated to 2005 using national accounts. ${ }^{2}$ There is also a recent literature on economic development that has stressed the role of differences in TFP as a major force in accounting for the large disparities in international income levels (Parente and Prescott, 2000; Prescott, 2002). In this paper, however, we focus exclusively on growth. 
and developing economies on the importance of plant dynamics in accounting for aggregate efficiency gains. ${ }^{3}$

The recent Chilean experience provides a rich setting to investigate these sources of efficiency gains. During the second half of the 1970s and the early 1980s, Chile carried out several market oriented reforms. Most distortions on prices and quantities were eliminated and producers were forced to compete in foreign markets. Overall, these reforms provided an environment that favored efficiency, both through the displacement of resources from less to more efficient producers and from the generalized adoption of better technologies and production processes. The study of plant-level productivity dynamics allows a complete understanding of these sources of aggregate growth.

In this paper we explore the connection between reallocation and productivity dynamics using 22 years of longitudinal data, covering the Chilean manufacturing sector. In our analysis we track the dynamics of productivity at the plant level, the entry and exit of plants, and the reshuffling of resources across continuing firms. Most papers studying the recent Chilean growth experience have only partially analyzed the available evidence, as they have missed the reallocation effects by concentrating exclusively on aggregate data. ${ }^{4}$ Other papers, such as Levinsohn and Petrin (2003), have identified reallocation effects in Chile using only data for 1979-86. Those papers, however, are unable to capture the complete dynamics resulting from reforms by focusing on a period of time too early and too short to allow these policies to fully affect the economy.

Our TFP estimates show the existence of productivity heterogeneity at the micro level. ${ }^{5}$ In particular, even within narrowly defined sectors, at any period of time there are wide differences in TFP. This heterogeneity suggests that reallocation can be a potentially important source of efficiency gains in Chile. Our results show this is indeed the case. By decomposing aggregate total factor productivity into production reallocation and within plant efficiency changes, we find that reallocation accounted for almost all of total efficiency gains in Chile over the past few decades. The entry of new, more productive firms drives most of these aggregate gains. Within-plant productivity growth contributes positively only during the 1990s, consistently with the existence of a lag between the implementation of major market oriented structural reforms -mostly undertaken during the late 1970s and early 1980s- and their complete effect on

\footnotetext{
${ }^{3}$ See Bartelsman and Doms (2000) for a recent review of the literature.

${ }^{4}$ For a recent analysis, see De Gregorio (2004).

${ }^{5}$ Since estimates of plant-level TFP are usually not available, it is common to use average labor productivity to study the connection between efficiency and the behavior of plants. TFP is, however, a better measure for two reasons. First, labor productivity is endogenous to TFP. Second, its evolution is determined not only by changes in multi-factor efficiency but also by the reallocation of inputs. The separate understanding of each of these sources of output per capita growth is quite relevant. For instance, while the former is unbounded and accounts for long-run growth, the latter is bounded by the efficient allocation of resources and correlates with the business cycle. Thus, a full characterization of aggregate efficiency allows a comprehensive understanding of long and short run growth.
} 
the economy. Once reforms were consolidated, unbounded within-plants efficiency gains driven by technology adoption and innovation occurred.

Market economies restructure continuously as a response to changing conditions. Our results, and those of a growing literature based on longitudinal databases at the micro level, suggest that productivity growth at the aggregate level is closely linked to the ability of the economy to efficiently reallocate inputs and outputs across firms. Thus barriers to this efficient reallocation process reduce aggregate efficiency and growth. For instance, a production subsidy to incumbent firms allows inefficient plants to stay longer in business. At the same time, more efficient firms that would have entered the market are left out. Financial restrictions, trade barriers, firm entry costs, inefficient bankruptcy procedures, bureaucratic red tape, tax burden, labor regulations, and the lack of human capital for technology adoption, all distort the natural process of resource reallocation. Chang et al. (2005), for instance, provide empirical evidence of a link between growth and measures of market flexibility and ease of entry and exit, whereas Hopenhayn and Rogerson (1993) and Bergoeing, Loayza and Repetto (2004) develop theoretical models showing that this link is a result of the ability of the economy to easily reshuffle resources towards more productive uses. These distortions have both static and dynamic effects. The resulting inefficient allocation of resources initially pushes the economy inside its production possibilities frontier. In the long run, because new firms are blocked out, the adoption of new and better technologies is delayed. In all cases, growth is reduced.

A number of papers have analyzed different aspects of plant-level TFP using Chilean data using similar estimation methods. Pavcnik (2002) studies the effects of trade reform on the behavior of within-plant productivity growth. She finds that TFP of continuous plants in import competing sectors grew much faster than plants in export oriented or nontraded sectors after trade was liberalized. Alvarez and López (2005a) compare the performance of exporters and non exporters. They find evidence of self-selection into export markets. They also find that plant TFP increases after plants begin to export, a fact consistent with learning by exporting. Bergoeing, Hernando and Repetto (2005b) study different aspects of the dynamics of TFP in the 1980s and the 1990s. Their results show that exiting plants experience a downward trajectory of productivity prior to exit, and that entering survivors quickly improve their productivity. They also show that more efficient plants are less likely to fail. Finally they show that all these effects were more pronounced in the 1990s than in the 1980s. Alvarez and López (2005b) look for productivity spillovers coming from export activity in manufacturing, in both downstream and upstream sectors. Their results suggest that there are positive forward spillovers, as exports in sectors producing intermediate inputs have a positive effect on the productivity of firms in downstream industries.

The current paper adds to this growing literature on plant-level TFP by connecting manufacturing aggregate efficiency to plant dynamics. The paper is organized as follows. The next section describes the manufacturing data we use, the estimation algorithm and the theoretical framework of firm exit behavior that 
supports it. In Section 3 we characterize plant-level TFP. In Section 4 we study the contribution of reallocation and within plant efficiency changes into aggregate productivity dynamics. The final section concludes.

\section{Plant Level Productivity: Data, Theory, and Estimation PROCEDURE}

In what follows we describe the data used in this study, a theory of plant exit and input demand based on plant specific productivity shocks, and the algorithm we use to estimate plant-level TFP based on this theory, originally developed by Olley and Pakes (1996).

The data

The data in this study come from the Encuesta Nacional Industrial Anual (ENIA), an annual survey of manufacturing conducted by the Chilean statistics agency, the Instituto Nacional de Estadísticas (INE). The ENIA covers all manufacturing plants that employ at least ten individuals. Thus, it includes all newly created and continuing plants with ten or more employees, and it excludes plants that ceased activities or reduced their hiring below the survey's threshold. The ENIA collects detailed information on plant characteristics, such as manufacturing sub-sector at the 4-digit ISIC level, sales, employment, investment, intermediate inputs and location. The available data cover the 1980-2001 period.

The treatment of entry and exit is somewhat complicated by the fact that plants falling below the minimum employment boundary do not appear in the survey. Thus a plant interviewed in any given year, but that fails to enter the sample in the following year might not represent an exit. Similarly, a plant appearing for the first time in any given year does not necessarily correspond to an entry, as it might represent a growing plant that surpasses the ten people boundary. To reduce the extent of spurious identification of plant entry and exit, we artificially raised the sample threshold to 15 employees, following the strategy in Micco (1995). ${ }^{6}$

Unfortunately, the ENIA does not report plant-level prices, so we constructed deflators at the 3-digit level from INE's wholesale price indices. The use of a common industry-level deflator might be problematic, as within-industry price differences are imputed as productivity shocks. ${ }^{7}$ Nominal output was thus deflated using these 3-digit ISIC level price indices. Deflators for materials were

\footnotetext{
${ }^{6}$ We also excluded plants that report no employment, no blue-collar workers, wages, no production days, zero gross production, negative value added, gross production lower then value added, exports larger than total sales, or no ISIC code.

${ }^{7}$ See Eslava et al. (2004) for the relative relevance of plant-level technology shocks vis a vis demand shocks.
} 
also constructed at the 3-digit ISIC level, using the 1996 input-output table. All real variables are expressed in 1992 Chilean pesos. Capital series were constructed using information on investment and depreciation (Bergoeing, Hernando and Repetto, 2005b).

We excluded the tobacco industry (314) and petroleum refineries (353) from the analysis, because they are organized as monopolies, operating with very few plants. The estimation strategy we use below assumes plant specific shocks are technology driven, and thus rules out markup shocks. Syverson (2004) shows that the failure of this assumption invalidates the strategy we use. ${ }^{8}$ The 27 subsectors used in this study account for $92 \%$ of total real gross revenue in the ENIA.

Table 1 presents some basic statistics of our data set at the 3-digit ISIC sector level. The first row shows mean values, whereas the second row shows standard errors. Entry and exit rates in the first two columns show some variation across sectors. Overall, 5.7\% and $6.3 \%$ of firms enter and exit the market in any given year, respectively. Gross output, capital stock and materials are expressed in (natural log of) 1992 Chilean pesos. Labor inputs are measured as the annual average of employees working at the firm, corrected by the number of days the firm operated in any given year. Electricity is directly measured in quantities, as the ENIA gathers information on electricity bought, sold and generated measured in thousands of KW per hour. Output and inputs also show wide variation across and within sectors, a fact consistent with idiosyncratic technology and efficiency differences. Across-plant shocks to efficiency lead to input purchase decisions that vary significantly even under identical production functions. Naturally, firms that hire more inputs and that produce more efficiently generate more output.

The theory

Assume the economy is populated by a continuum of heterogeneous firms, each one with its own level of productivity. ${ }^{9}$ In every period, given factor prices and the market structure, the manager of each firm decides whether to quit production and exit, or to stay in business. The exit decision is irreversible. The manager's decisions are made after facing an idiosyncratic productivity shock that is a random draw from an exogenous Markov process. If the firm continues in operation, the manager purchases variable factors and chooses investment. If the plant quits production, the plant is worth a sell-off value equal to Y. Exit decisions are based on maximizing expected discounted net cash flows. The firm's problem is

$$
V_{t}\left(\omega_{t}, k_{t}\right)=\max \left\{\Psi, \sup _{i_{t} \geq 0} \pi_{t}\left(\omega_{t}, k_{t}\right)-c\left(i_{t}\right)+\beta E_{t} V_{t+1}\left(\omega_{t+1}, k_{t+1}\right)\right\}
$$

\footnotetext{
${ }^{8}$ See the estimation strategy section below for a discussion.

${ }^{9}$ In this paper we refer to firms and plants as equivalent economic units, although our data set collects information on plants and not on firms. According to Central Bank statisticians, about $3.5 \%$ of plants belong to a multi-plant firm in our data set.
} 
TABLE 1

BASIC STATISTICS AT THE SECTOR LEVEL

(Mean and Standard Deviation)

\begin{tabular}{|c|c|c|c|c|c|c|c|c|}
\hline & $\begin{array}{l}\text { Entry } \\
\text { Rate }\end{array}$ & $\begin{array}{l}\text { Exit } \\
\text { Rate }\end{array}$ & $\begin{array}{l}\text { Gross } \\
\text { Output }\end{array}$ & $\begin{array}{l}\text { Unskilled } \\
\text { Labor }\end{array}$ & $\begin{array}{l}\text { Skilled } \\
\text { Labor }\end{array}$ & $\begin{array}{c}\text { Capital } \\
\text { Stock }\end{array}$ & Electricity & Materials \\
\hline \multirow[t]{2}{*}{311} & 0.053 & 0.059 & 12.62 & 3.65 & 1.56 & 10.78 & 4.45 & 12.08 \\
\hline & 0.224 & 0.236 & 1.60 & 1.10 & 1.24 & 2.12 & 1.83 & 1.64 \\
\hline \multirow[t]{2}{*}{312} & 0.059 & 0.059 & 13.64 & 3.71 & 2.08 & 11.92 & 5.28 & 12.94 \\
\hline & 0.235 & 0.236 & 1.82 & 1.16 & 1.42 & 2.02 & 1.84 & 2.02 \\
\hline \multirow[t]{2}{*}{313} & 0.041 & 0.068 & 13.99 & 3.95 & 2.47 & 12.38 & 5.23 & 12.88 \\
\hline & 0.198 & 0.252 & 1.78 & 1.11 & 1.43 & 2.08 & 1.78 & 1.84 \\
\hline \multirow[t]{2}{*}{321} & 0.043 & 0.059 & 12.89 & 3.66 & 1.54 & 11.22 & 4.63 & 12.01 \\
\hline & 0.204 & 0.236 & 1.35 & 1.13 & 1.29 & 1.74 & 1.71 & 1.41 \\
\hline \multirow[t]{2}{*}{322} & 0.063 & 0.084 & 12.38 & 3.55 & 1.37 & 10.38 & 3.62 & 11.75 \\
\hline & 0.243 & 0.277 & 1.25 & 1.04 & 1.16 & 1.62 & 1.24 & 1.30 \\
\hline \multirow[t]{2}{*}{323} & 0.040 & 0.068 & 13.02 & 3.61 & 1.61 & 11.01 & 4.59 & 12.30 \\
\hline & 0.197 & 0.252 & 1.41 & 0.95 & 1.03 & 1.84 & 1.67 & 1.51 \\
\hline \multirow[t]{2}{*}{324} & 0.054 & 0.067 & 12.62 & 3.79 & 1.37 & 10.55 & 3.87 & 11.97 \\
\hline & 0.226 & 0.250 & 1.34 & 1.12 & 1.20 & 1.82 & 1.43 & 1.27 \\
\hline \multirow[t]{2}{*}{331} & 0.077 & 0.086 & 12.80 & 3.86 & 1.35 & 11.10 & 4.82 & 11.92 \\
\hline & 0.267 & 0.281 & 1.42 & 1.08 & 1.14 & 1.85 & 1.68 & 1.52 \\
\hline \multirow[t]{2}{*}{332} & 0.076 & 0.087 & 12.08 & 3.51 & 1.23 & 10.38 & 3.78 & 11.38 \\
\hline & 0.266 & 0.282 & 1.36 & 1.02 & 1.11 & 1.80 & 1.40 & 1.37 \\
\hline \multirow[t]{2}{*}{341} & 0.067 & 0.061 & 13.80 & 4.04 & 2.35 & 12.48 & 5.81 & 13.02 \\
\hline & 0.251 & 0.239 & 1.90 & 1.29 & 1.61 & 2.39 & 2.67 & 1.94 \\
\hline \multirow[t]{2}{*}{342} & 0.049 & 0.062 & 12.50 & 3.24 & 1.67 & 11.20 & 3.97 & 11.36 \\
\hline & 0.216 & 0.241 & 1.37 & 1.08 & 1.30 & 1.76 & 1.40 & 1.53 \\
\hline \multirow[t]{2}{*}{351} & 0.064 & 0.047 & 13.96 & 3.57 & 2.21 & 12.45 & 6.02 & 12.88 \\
\hline & 0.245 & 0.211 & 1.60 & 1.15 & 1.35 & 1.96 & 2.30 & 1.71 \\
\hline \multirow[t]{2}{*}{352} & 0.041 & 0.044 & 13.88 & 3.54 & 2.61 & 12.11 & 4.71 & 12.96 \\
\hline & 0.198 & 0.206 & 1.49 & 1.17 & 1.31 & 1.82 & 1.58 & 1.50 \\
\hline \multirow[t]{2}{*}{354} & 0.055 & 0.049 & 13.92 & 3.62 & 2.06 & 12.22 & 5.40 & 13.17 \\
\hline & 0.229 & 0.216 & 1.69 & 0.98 & 1.24 & 1.84 & 1.25 & 1.76 \\
\hline \multirow[t]{2}{*}{355} & 0.046 & 0.050 & 12.58 & 3.49 & 1.66 & 11.25 & 4.94 & 11.69 \\
\hline & 0.209 & 0.217 & 1.42 & 1.12 & 1.19 & 1.77 & 1.53 & 1.53 \\
\hline
\end{tabular}


(Cont. Table 1)

\begin{tabular}{|c|c|c|c|c|c|c|c|c|}
\hline & $\begin{array}{l}\text { Entry } \\
\text { Rate }\end{array}$ & $\begin{array}{l}\text { Exit } \\
\text { Rate }\end{array}$ & $\begin{array}{l}\text { Gross } \\
\text { Output }\end{array}$ & $\begin{array}{c}\text { Unskilled } \\
\text { Labor }\end{array}$ & $\begin{array}{c}\text { Skilled } \\
\text { Labor }\end{array}$ & $\begin{array}{l}\text { Capital } \\
\text { Stock }\end{array}$ & Electricity & Materials \\
\hline \multirow[t]{2}{*}{356} & 0.075 & 0.053 & 13.00 & 3.68 & 1.72 & 11.55 & 5.43 & 12.11 \\
\hline & 0.264 & 0.224 & 1.29 & 1.04 & 1.13 & 1.72 & 1.59 & 1.39 \\
\hline \multirow[t]{2}{*}{361} & 0.058 & 0.070 & 12.68 & 4.27 & 1.90 & 11.15 & 5.87 & 11.29 \\
\hline & 0.235 & 0.256 & 1.77 & 1.38 & 1.48 & 2.08 & 1.47 & 1.85 \\
\hline \multirow[t]{2}{*}{362} & 0.028 & 0.045 & 13.26 & 4.07 & 2.15 & 11.91 & 5.40 & 11.98 \\
\hline & 0.164 & 0.208 & 1.69 & 1.16 & 1.36 & 2.14 & 2.07 & 1.57 \\
\hline \multirow[t]{2}{*}{369} & 0.060 & 0.056 & 12.86 & 3.63 & 1.60 & 11.35 & 4.77 & 11.73 \\
\hline & 0.237 & 0.230 & 1.67 & 1.03 & 1.31 & 2.16 & 2.07 & 1.70 \\
\hline \multirow[t]{2}{*}{371} & 0.054 & 0.048 & 13.93 & 4.24 & 2.45 & 12.50 & 6.30 & 12.94 \\
\hline & 0.227 & 0.214 & 1.82 & 1.30 & 1.47 & 1.91 & 2.35 & 1.89 \\
\hline \multirow[t]{2}{*}{372} & 0.057 & 0.051 & 15.24 & 4.48 & 3.09 & 13.40 & 7.49 & 14.37 \\
\hline & 0.232 & 0.220 & 2.63 & 1.63 & 1.80 & 2.61 & 3.03 & 2.85 \\
\hline \multirow[t]{2}{*}{381} & 0.060 & 0.060 & 12.83 & 3.61 & 1.64 & 10.96 & 4.41 & 11.88 \\
\hline & 0.238 & 0.238 & 1.39 & 1.01 & 1.18 & 1.88 & 1.49 & 1.46 \\
\hline \multirow[t]{2}{*}{382} & 0.064 & 0.058 & 12.62 & 3.50 & 1.76 & 11.15 & 4.37 & 11.61 \\
\hline & 0.245 & 0.233 & 1.41 & 1.14 & 1.27 & 1.73 & 1.44 & 1.55 \\
\hline \multirow[t]{2}{*}{383} & 0.049 & 0.049 & 13.31 & 3.73 & 2.08 & 11.65 & 4.71 & 12.29 \\
\hline & 0.216 & 0.216 & 1.54 & 1.07 & 1.30 & 1.84 & 1.68 & 1.44 \\
\hline \multirow[t]{2}{*}{384} & 0.062 & 0.066 & 12.44 & 3.60 & 1.70 & 11.30 & 4.42 & 11.59 \\
\hline & 0.240 & 0.248 & 1.67 & 1.12 & 1.26 & 1.81 & 1.51 & 1.81 \\
\hline \multirow[t]{2}{*}{385} & 0.040 & 0.032 & 12.85 & 3.32 & 1.79 & 11.33 & 4.30 & 11.70 \\
\hline & 0.197 & 0.175 & 1.19 & 0.90 & 1.14 & 1.37 & 1.27 & 1.24 \\
\hline \multirow[t]{2}{*}{390} & 0.043 & 0.053 & 12.30 & 3.29 & 1.41 & 10.53 & 3.86 & 11.22 \\
\hline & 0.203 & 0.224 & 1.07 & 0.79 & 0.97 & 1.63 & 1.22 & 1.16 \\
\hline \multirow[t]{2}{*}{ All } & 0.057 & 0.063 & 12.85 & 3.65 & 1.67 & 11.13 & 4.57 & 12.04 \\
\hline & 0.232 & 0.242 & 1.58 & 1.11 & 1.29 & 2.00 & 1.80 & 1.63 \\
\hline
\end{tabular}

Source: Authors' estimates.

The first row shows the mean, whereas the second row shows the standard deviation.

Outputs and inputs are expressed in natural logs.

where the function $\mathrm{c}(\bullet)$ represents the cost of investment, $\beta$ the firm's discount factor, $E_{t}$ the expectation operator conditional on all information known at time $t$, and $V_{t}$ the value function at period $t$. The profit function of the firm is represented by $\pi_{t}\left(\omega_{t}, k_{t}\right)$, which depends on the current value of the state variables, capital $\left(k_{t}\right)$ and productivity $\left(\omega_{t}\right)$. The function is indexed by time to account for changing 
market structures and factor and output prices. The law of motion for capital is given by

$$
k_{t+1}=(1-\delta) k_{t}+i_{t}
$$

where $i_{t}$ is current period's gross investment.

Conditional on capital stock, $k_{t}$, equilibrium exit decisions are given by a cut-off level of productivity $\omega^{*}{ }_{\tau}\left(k_{t}\right)$ as shown by Ericson and Pakes (1995). If $\omega_{\tau} \geq \omega_{\tau}^{*}\left(k_{t}\right)$ the firm stays in business, and if $\omega_{\tau}<\omega_{\tau}^{*}\left(k_{t}\right)$, the firm exits. This cutoff is decreasing in $k_{t}$ if the difference between the expected discount value of profits and the sell-off value depends positively on capital; i.e. larger firms lose more if they choose to quit. In other words, a larger capital stock allows firms to stay in business even if current productivity is relatively low. Finally, if a plant stays, its investment demand is given by $i_{t}=i_{t}\left(\omega_{t}, k_{t}\right)$. Pakes (1994) shows that for any capital stock, the investment function $i_{t}$ is strictly increasing in $\omega_{t}$, whenever investment is strictly positive. The monotonicity of the cut-off and investment demand functions are a key ingredient for the algorithm originally developed by Olley and Pakes (1996) and further extended by Levinsohn and Petrin (2003) that is outlined in the next subsection.

\section{The Olley-Pakes and Levinsohn-Petrin estimation strategies}

The first step in constructing series of TFP is estimating a production function. Within this theoretical framework, the empirical estimation of production functions is problematic because productivity, a state variable in the firm's decision problem, is not observed by the econometrician. Two biases in OLS estimation of the production functions are introduced. First, there is a simultaneity problem, as factor demands are correlated with the unobserved productivity term. Specifically, if firms with higher productivity are more likely to purchase inputs, then OLS estimates of the corresponding coefficients are biased upwards. ${ }^{10}$ Second, there is a selection problem since conditional on survival the econometrician only observes plants with productivity greater than the cut-off. The expectation of productivity depends negatively on capital since firms with a larger capital stock can afford to survive with a lower productivity level. Thus, the capital coefficients are biased downwards.

Fixed effects regressions do not solve the simultaneity problem since they require the productivity term to be constant over time. Given the length of the period considered and since structural reforms were undertaken during the period studied, it is highly unlikely that productivity remained constant. As a matter of fact, the results in Pavcnik (2002) for the 1979-86 period suggest that fixed effects regressions do not fully control for the endogeneity problem, and thus that plantlevel productivity is not constant over time. Similarly, balancing the panel of

\footnotetext{
${ }^{10}$ See Griliches and Mairesse (1995) for a thorough analysis of the simultaneity problem.
} 
firms does not solve the selection problem, since firms that remain in the panel are firms that survived.

To circumvent these problems we use a general estimation procedure proposed by Olley and Pakes (OP) and modified by Levinsohn and Petrin (LP). ${ }^{11}$

Let the production function of firm $i$ at time $t$ be

$$
y_{i t}=\beta_{0}+\beta_{s} l^{s}{ }_{i t}+\beta_{u} l^{u}{ }_{i t}+\beta_{k} k_{i t}+\beta_{m} m_{i t}+\omega_{i t}+\mu_{i t}
$$

where $y_{i t}$ is log of firm's i gross output at time $t$. The variable inputs of production are $l^{s}{ }_{i t}$ (the $\log$ of skilled labor), $l^{u}{ }_{i t-}$ (the log of unskilled labor), and $m_{i t}$ (the log of intermediate inputs-energy and materials). The natural logarithm of the stock of capital, $k_{i t}$, is a state variable. The unobserved shock $\omega_{i t}$ is the log of plantspecific productivity, whereas $\mu_{i t}$ is a mean zero error that accounts for measurement error and for unexpected productivity shocks that do not affect the choice of inputs. The former random shock is a state variable of the problem, whereas the latter is not.

OP uses the fact that the investment demand depends upon the current state variables, but does not affect current production. Thus investment can be used as a proxy for the unobserved productivity shock. Specifically, $\omega_{i t}$ is approximated by a polynomial expansion in investment and capital. The selection problem is corrected through an intermediate step in which the exit probability of any given plant is estimated using polynomial expansions in capital and investment. This estimated exit probability is later used to control for the cut-off level productivity under which a plant exits.

A major limitation of the Olley-Pakes strategy is investment lumpiness: a large number of firms report zero investment in many years. Unfortunately, the invertibility of the investment demand function depends crucially upon observing strictly positive investment. LP shows that intermediate inputs can also be used as proxies for productivity, as their demand also depends upon the state variables of the problem. Thus, instead of using polynomials in investment and capital, the strategy uses polynomials in intermediate inputs and capital. LP use the orthogonally conditions of the problem -i.e., current capital stock and lagged variable input demands are not correlated with current productivity innovationsand GMM to identify the coefficients of the production function. The method allows for the test of overidentifying restrictions.

The dataset and the estimation method have a number of limitations that might induce to error in our estimations of TFP below. First, we do not observe labor effort, labor hoarding and capital utilization. If these vary, the growth rate of observed inputs does not fully capture their service flows. Second, the algorithm used and described below assumes that productivity is the only unobserved plantspecific state variable. ${ }^{12}$ Instrumental variables techniques are preferred in cases

\footnotetext{
${ }^{11}$ See Olley and Pakes (1996), and Levinsohn and Petrin (2003).

${ }^{12}$ Different market structures are allowed, but these must be either constant over time or random in such a way that it does not represent a state variable of the firm.
} 
where other shocks, such as demand shocks, are relevant. Unfortunately, obtaining good instruments at the plant level is a difficult task in most cases. An exception is Syverson (2004) that uses market segmentation in the ready-mix concrete industry to identify an exogenous source of variability in demand. Third, we do not allow for externalities from the activity of other firms. Fourth, we assume that all firms within a 3-digit industry use the same production function. Idiosyncratic productivity shocks are the only difference across firms within an industry. Finally, we assume that output elasticities are constant over time.

\section{The Dynamics of Plant-level Productivity in Chile}

In this section we characterize the estimates of plant-level TFP. We use these measures to describe the evolution of productivity over time. The TFP estimates behave according to expected patterns. Moreover, we find extensive heterogeneity in micro efficiency, a necessary condition for reallocation to be a relevant source of aggregate efficiency.

Production function estimates

We use the LP estimation strategy to estimate production functions for gross revenue, with electricity demand as the proxy for productivity. ${ }^{13}$ The LP estimation method allows for the use of any intermediate input (lagged) as an instrument in the GMM identification equations. We chose electricity because quantities are directly measured at the plant-level in the ENIA. Materials must be deflated, introducing possible biases as we lack data on process at the individual level. ${ }^{14}$

Gross production, and not value added, is the correct output concept at this level of disaggregation. GDP is a value added measure as the economy uses capital and labor for producing goods and services. Intermediate inputs are netted out in the aggregation process. Alternatively, gross output is the right measure at the plant level as plants' output consists of final and intermediate goods. Firms combine capital, labor and intermediate inputs (materials and energy) to produce this gross output. ${ }^{15}$

Table 2 presents the estimated elasticities of unskilled (blue collar) and skilled labor, capital, materials and electricity and their bootstrapped standard errors. The reported elasticities exhibit wide variation across sectors. Most coefficients are precisely estimated. Only capital cannot be precisely estimated in many sectors, perhaps due to its little variability over time, as investment

\footnotetext{
${ }^{13}$ Only a very small fraction of observations report no electricity consumption (about $1.5 \%$ of them.) Some plants generate and sell electricity. Our measure of electricity is consumption plus generation minus sales.

${ }^{14}$ Results using materials as a proxy instead are available upon request.

${ }^{15}$ See Basu and Fernald (1995) for a discussion on production functions at different levels of aggregation.
} 


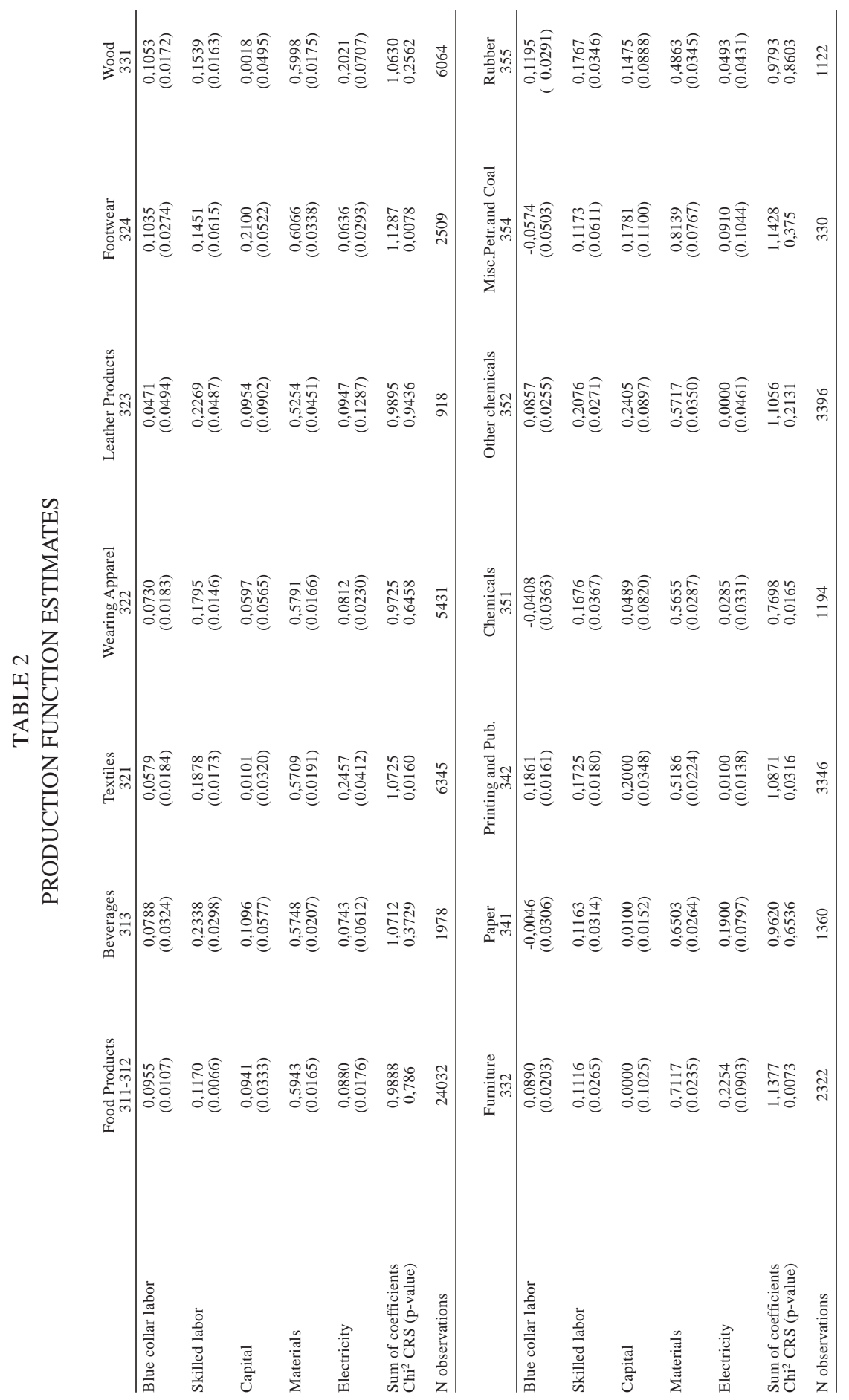




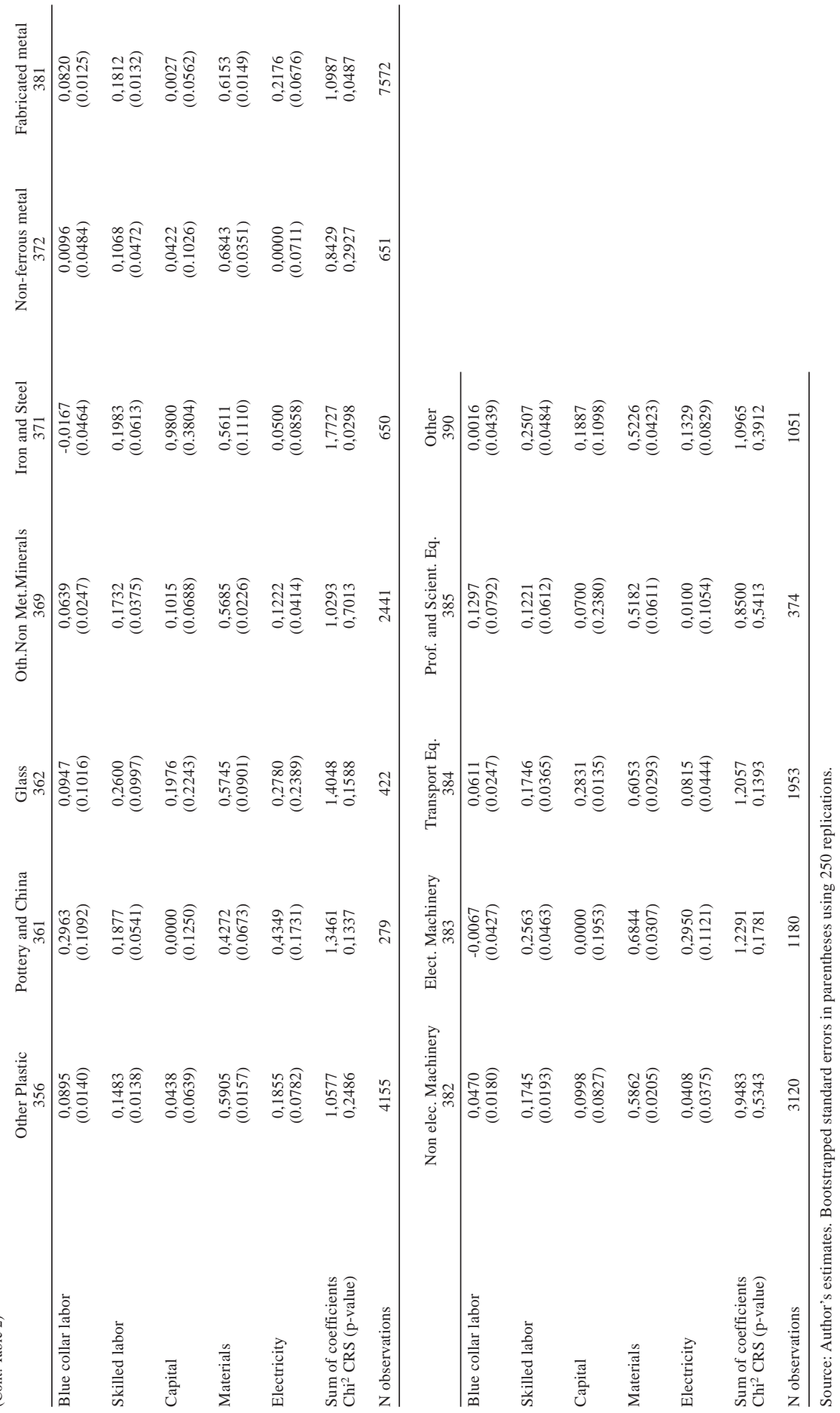


behaves in a lumpy manner. In about $75 \%$ of sectors, the null hypothesis of constant returns to scale cannot be rejected.

The estimated degrees of returns to scale vary from 0.77 (chemical industry) to 1.77 (iron and steel basic industries). The largest elasticity of unskilled labor corresponds to the manufacturing of china, pottery and earthenware, a point elasticity of 0.30 . The most skilled-labor elastic sector is the manufacture of glass products, with an elasticity of 0.26 . The statistically significant coefficients on capital vary between 0.09 (food products) and 0.98 (iron and steel basic industries).

Pavcnik (2002), using data from the ENIA, obtains elasticities that are quite different from those presented here. She uses a much shorter data set (up to 1986 only), and the OP strategy with investment as a proxy to perform her estimates. Moreover, although she includes materials, she excludes energy from the analysis. Levinsohn and Petrin (2003) perform estimates for four 3-digit sectors (311, 321, 331 and 381), using the same sub-sample of the ENIA that Pavcnik uses. Although we get different point estimates, most of the coefficients they obtain are of the same order of magnitude as ours. Since we use the same methodology and proxies as LP, the differences in coefficients must be due to the samples and deflators used, and to the LP assumption that investment becomes productive immediately.

\section{Characterizing plant-level productivity}

Next, we characterize the dynamics over time of our estimates of TFP. Let $\hat{\omega}_{i t}$ represent the estimated of the level of TFP of plant $i$ at time period $t$, using the production coefficients previously estimated with the LP version of the algorithm. That is,

$$
p_{i t}=\hat{\omega}_{i t}=y_{i t}-\hat{\beta}_{k} k_{i t}-\hat{\beta}_{s} l_{i t}^{s}-\hat{\beta}_{u} l_{i t}^{u}-\hat{\beta}_{m} m_{i t}
$$

Following the literature, we define aggregate productivity at the 3-digit industry level as

$$
\Omega_{t}=\sum_{i} \theta_{i t} \exp \left(\hat{\omega}_{i t}\right)
$$

where $\theta_{i t}$ is the share of plant's $i$ gross revenue in sectoral gross revenue at time $t$. Figures $2 \mathrm{a}-2 \mathrm{c}$ displays the full dynamics of this weighted average productivity at the industry level. All series are normalized to 100 in 1980. Sectors were classified according to their average productivity growth rate over the period. These rates vary from $-2.3 \%$ and $7.1 \%$ per year (sectors 342 , printing and publishing, and 372, non-ferrous metal industries, respectively). Although productivity fluctuates largely over time, 23 out of the 27 sectors display a positive annual average productivity growth, indicating that most manufacturing sectors 


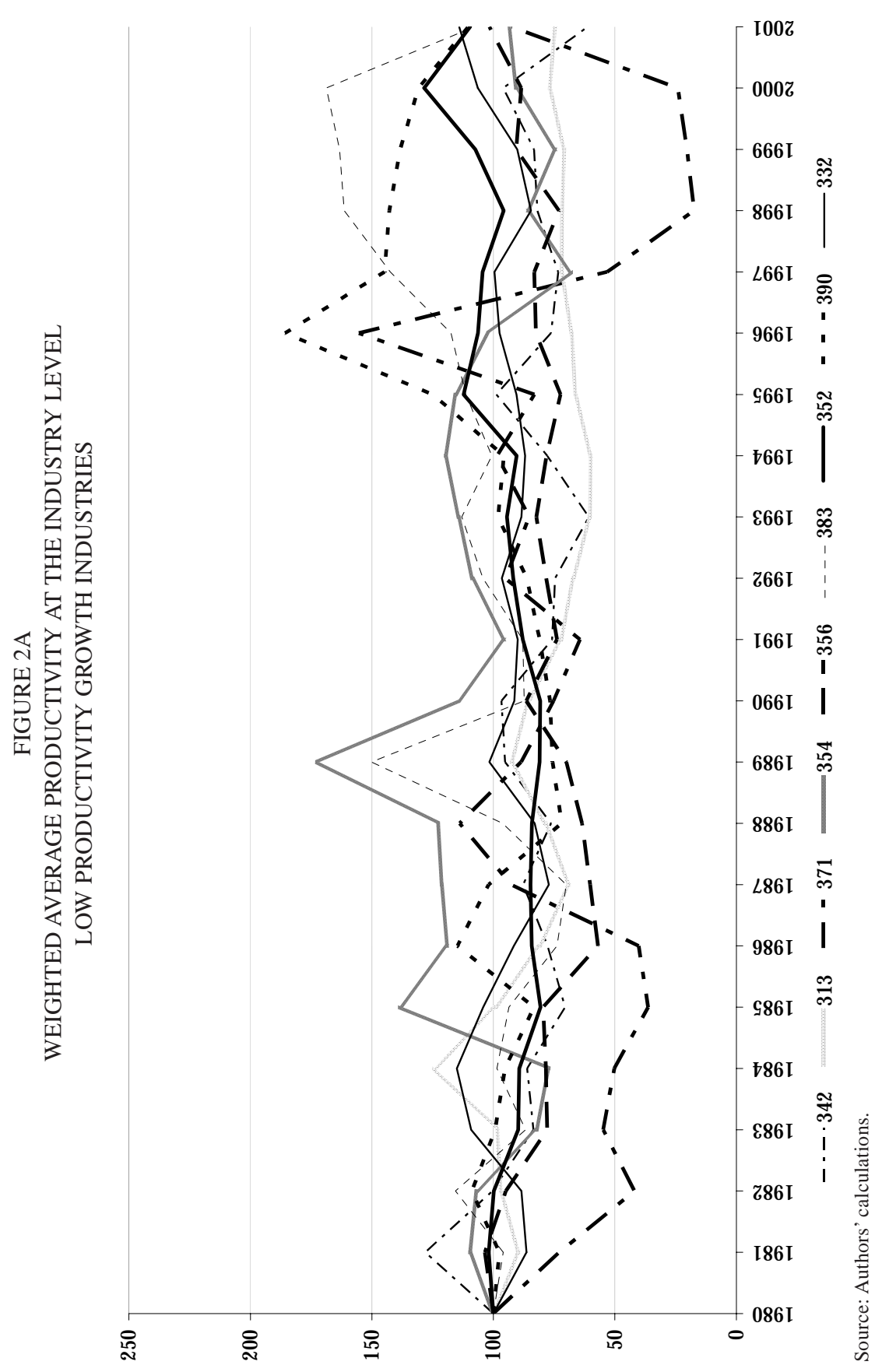




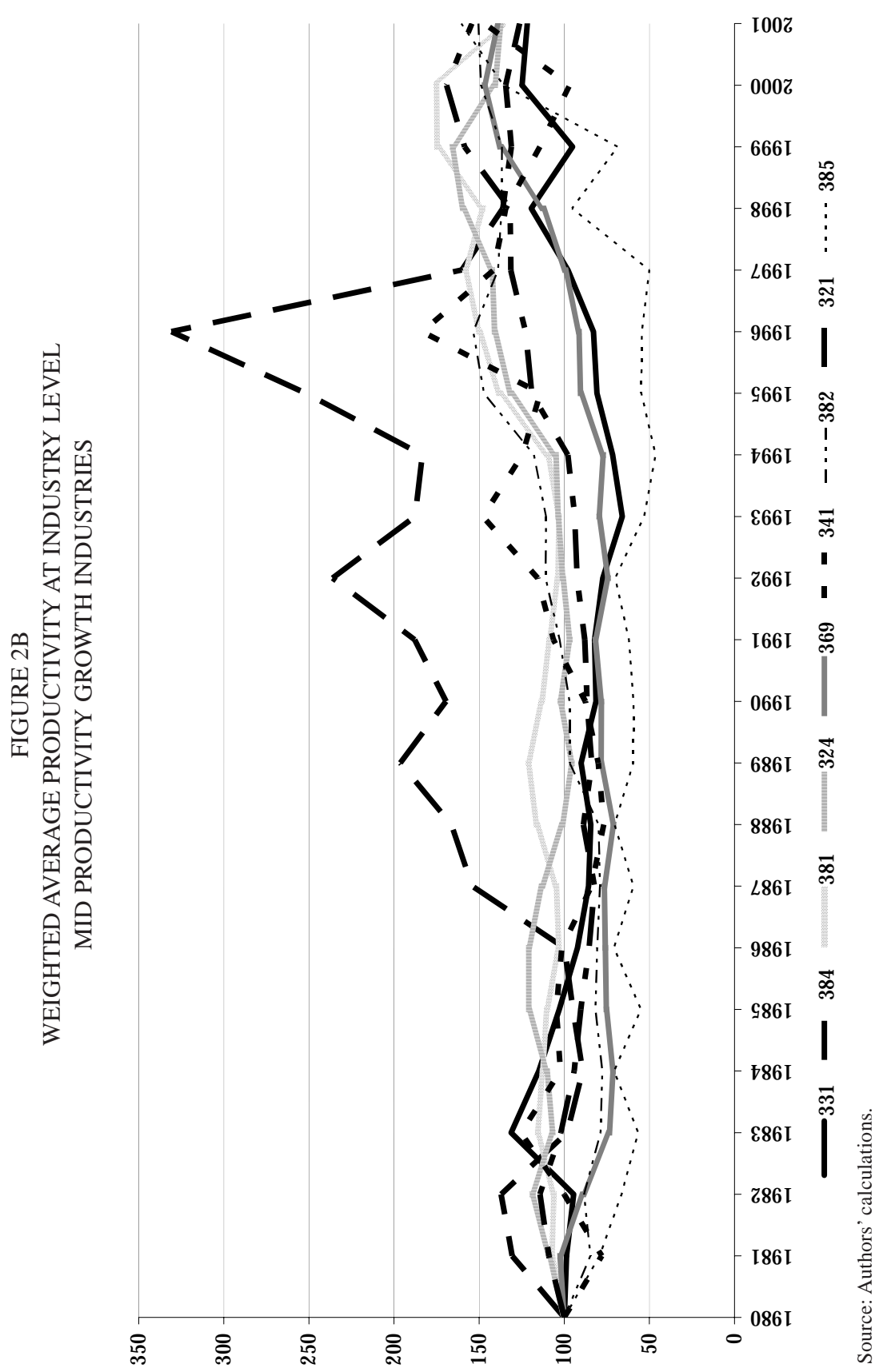




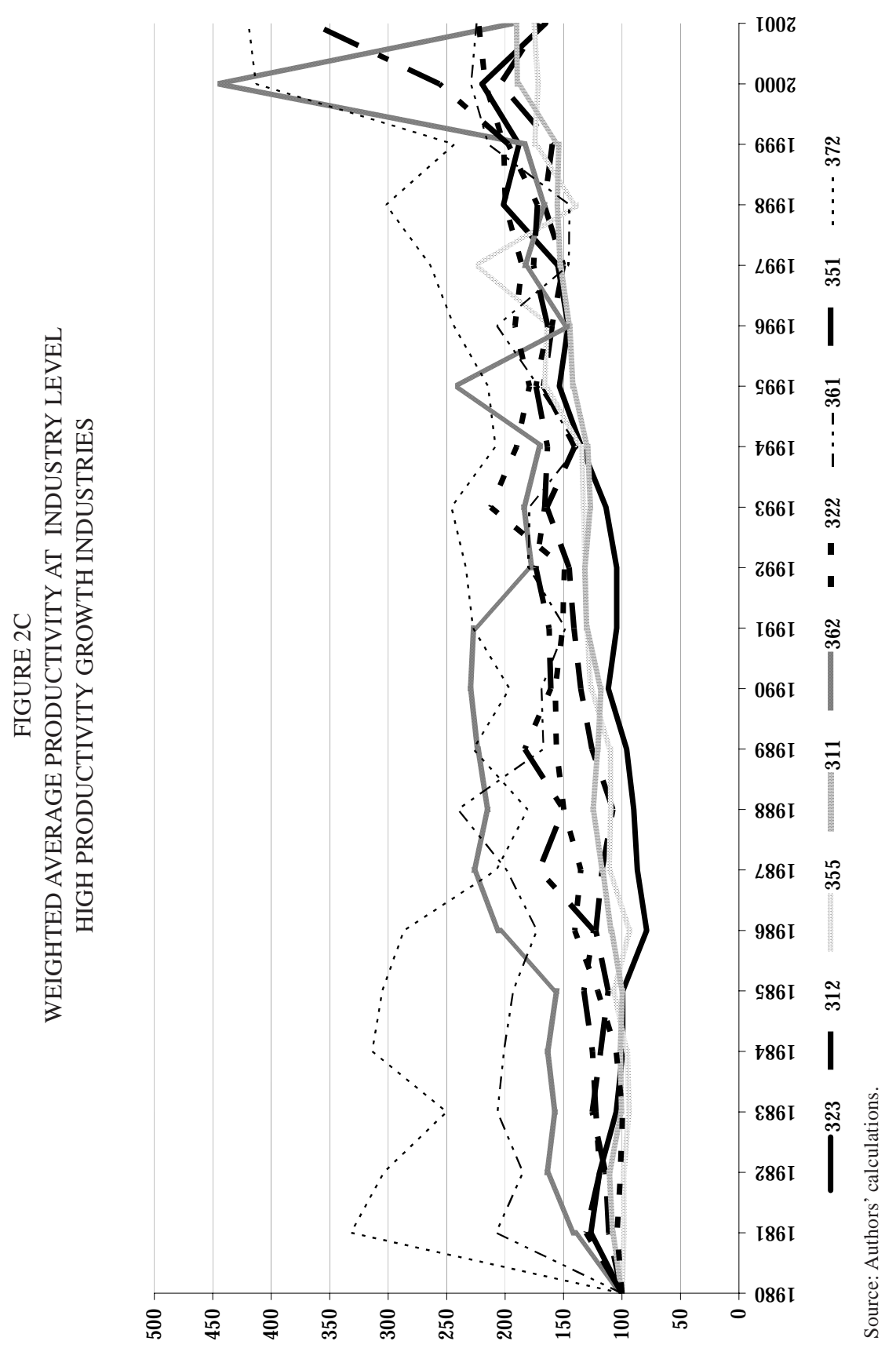


have become more productive in Chile over the period of analysis - the exception being sectors $313,342,354$ and 371 . In other words, mean productivity growth is positive reflecting that, over time, industries are growing faster than inputs.

Our estimates of TFP show that there are wide differences in efficiency levels, even within a sector in any given year. Figure 3 provides evidence of such heterogeneity. The figure shows the ratio of productivity for plants in the ninetieth percentile of the productivity distribution relative to the productivity of plants in the tenth percentile. These ratios are large, ranging from 8.1 to 11.6. Calculations for specific three-digit sectors are consistent. These large differences in productivity are a necessary condition for reallocation to be a quantitatively relevant source of efficiency gains.

FIGURE 3

TFP DISPERSION

ALL SECTORS

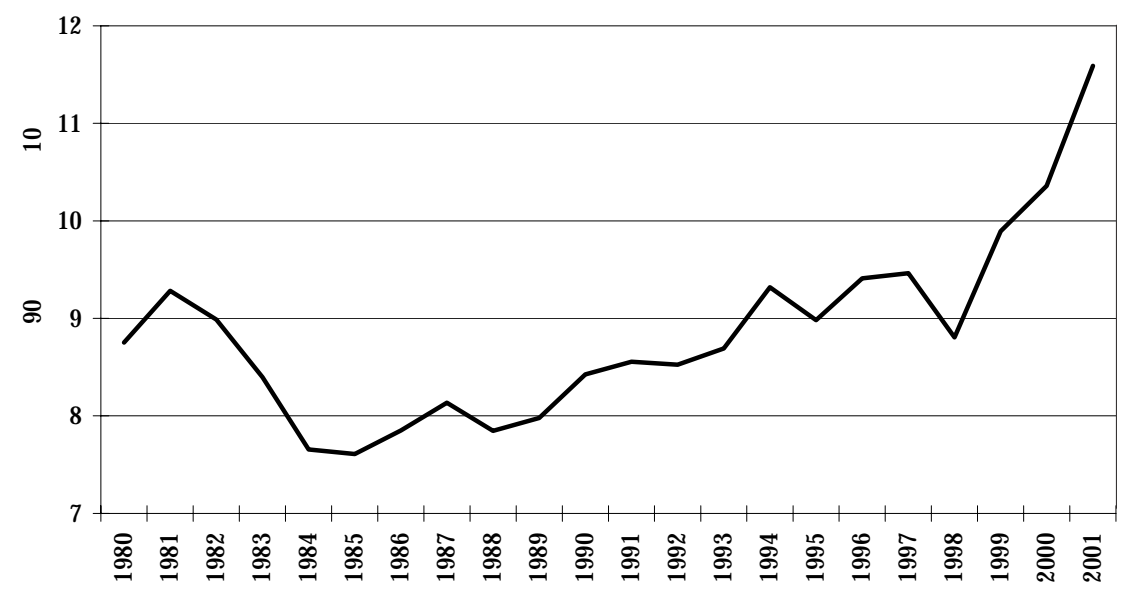

Source: Authors' calculations.

It is interesting to note that over the 1990s, plant-level dispersion increased, in spite of the reduction in aggregate volatility relative to the $1980 \mathrm{~s} .{ }^{16}$ This higher relative heterogeneity during the 1990s may reflect a higher degree of flexibility after the full implementation of market structural reforms a decade earlier. ${ }^{17}$ Greater flexibility allows for a more heterogeneous group of firms to enter the market and for greater process experimentation, as credit markets deepened and bankruptcy laws and dismissal costs were lowered. Moreover, trade

\footnotetext{
${ }^{16}$ Comin and Mulani (2005) shows that volatility at the aggregate level has decreasead in Canada and the US over the past two decades, meanwhile volatility at the firm level has increased.

${ }^{17}$ Eslava et al. (2004) also find that productivity heterogeneity increased after major reforms were implemented in Colombia.
} 
reform segmented firms into those that export and those that do not, depending upon their efficiency. Trade opening selected the best firms into export markets, those who could profitably pay the costs of exporting, and left the less efficient surviving firms to exclusively produce for the domestic market. ${ }^{18}$ Finally, the rise in TFP dispersion is also consistent with increases in market segmentation, as less productive plants can survive whenever there are departures from complete output homogeneity.

In general, our estimates of plant-level efficiency are consistent with expected patterns. For instance, Figure 4 presents the cumulative distribution of productivity for incumbent plants, shutdowns and startups. No matter the level of productivity, the TFP distribution of plants that exit is to the left of the distribution of productivity of continuing plants. In other words, the probability of exceeding any given level of productivity is higher among continuing plants than shutdowns, and thus the first distribution first order stochastically dominates the second one. The Barrett and Donaldson (2003) test does not reject the hypothesis of first order stochastic dominance in both cases. The p-values are $7.15 \%$ for the comparison between the CDF of continuing plants and entrants, and $0.00 \%$ for the comparison between the CDF of continuing plants and shutdowns. ${ }^{19}$ Moreover, bigger, older, and more outward oriented plants are more productive. ${ }^{20}$

FIGURE 4

CUMULATIVE DISTRIBUTION OF TFP

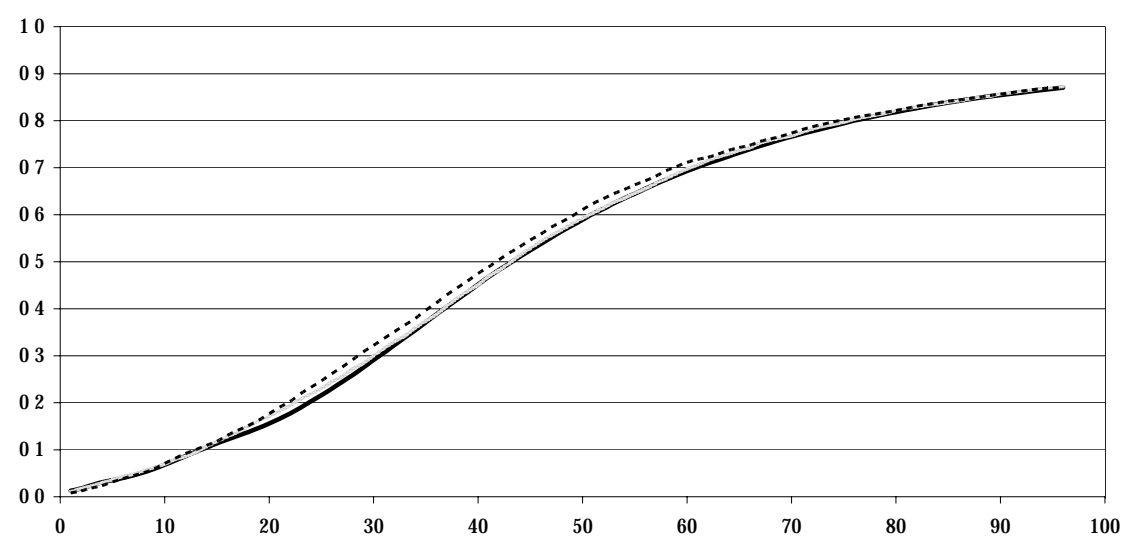

Source: Authors' calculations.

\footnotetext{
${ }^{18}$ See Melitz (2003) for a theoretical model and Bergoeing, Micco and Repetto (2005) for Chilean evidence.

${ }^{19}$ The test rejects the hypothesis that the distribution of TFP of entrants stochastically dominates that of shutdowns, and viceversa.

${ }^{20}$ See Bergoeing, Hernando and Repetto (2005b) for a complete characterization of Chilean plantlevel productivity dynamics.
} 


\section{The Micro Sources of Aggregate Productivity in Chile}

In this section we use our estimates of plant-level TFP to study the microeconomic sources of aggregate growth in Chile during the past two decades. We do so by disentangling aggregate productivity dynamics into two processes: first, the changes in efficiency within firms; second, the reallocation arising from the expansion and contraction of continuing plants as well as from the entry and exit of economic units.

We follow Foster, Haltiwanger, and Krizan (1998) in decomposing productivity growth into four elements: (i) a within-plant effect, given by incumbents' productivity growth weighted by initial output shares; (ii) a betweenplant effect, that captures the gains in aggregate productivity coming from the expanding market share of high productivity plants relative to the initial aggregate productivity level; (iii) an entry effect which is the sum of the differences between each entering plant's productivity and initial aggregate productivity, weighted by its market share; and (iv) an exit effect given by the sum of the differences between each exiting plant's productivity and initial aggregate productivity, weighted by its market share. ${ }^{21}$ The decomposition is given by:

$$
\begin{aligned}
& \Delta P_{t}= \sum_{i \in C} \theta_{i t-k} \Delta p_{i t}+\sum_{i \in C}\left(\Delta \theta_{i t}\right)\left(p_{i t}-P_{t-k}\right) \\
&+\sum_{i \in N} \theta_{i t}\left(p_{i t}-P_{t-k}\right)-\sum_{i \in X} \theta_{i t-k}\left(p_{i t-k}-P_{t-k}\right)
\end{aligned}
$$

where $\Delta$ refers to changes over the $k$-year interval; $P_{t}$ is the log aggregate productivity level of the sector in year $\mathrm{t}$; $\theta_{i t}$ is the share of plant's $i$ value added in sectoral value added at time $t$, and $C, N$, and $X$ are sets of continuing, entering, and exiting plants, respectively. Thus, incumbents contribute to aggregate log productivity growth if they become more efficient, or if the more productive plants increase their market share. New plants contribute positively to productivity growth whenever their higher productivity is higher than the initial industry average. Exiters do so whenever they are less productive than the initial industry average. The last three terms of the decomposition capture the effects of heterogeneity. If all plants were identical, then the within-continuers effect would constitute the only source of aggregate gains.

Table 3 displays our decomposition results. We report them for the full period and four sub-periods: 1981-83, 1983-90, 1990-97, and 1997-2001. We also present total log TFP growth using total GDP from national accounts for comparison. Over the early 80 s crisis, aggregate manufacturing TFP in the ENIA grew due to the reallocation of resources. Thus TFP growth reduced the extent of the crisis within the manufacturing sector. Plants that failed were less productive

${ }^{21}$ There exist several alternative decomposition methods that follow this tradition. See Foster, Haltiwanger, and Krizan (1998) for further discussions on alternative decomposition methods. 
TABLE 3

DECOMPOSITION OF LOG TFP GROWTH IN MANUFACTURING

\begin{tabular}{|c|c|c|c|c|c|c|c|c|}
\hline & \multicolumn{2}{|c|}{ Total Change } & \multicolumn{6}{|c|}{ Decomposition of TFP Growth in ENIA } \\
\hline & \multirow{2}{*}{$\begin{array}{l}\text { National } \\
\text { Accounts }\end{array}$} & \multirow{2}{*}{$\begin{array}{l}\text { Manufact. } \\
\text { ENIA }\end{array}$} & \multicolumn{2}{|c|}{ Incumbents } & \multirow[b]{2}{*}{ Entry } & \multirow[b]{2}{*}{ Exit } & \multicolumn{2}{|c|}{$\%$ of Total } \\
\hline & & & Within & Across & & & Within & Total Realloc. \\
\hline 1983-1981 & -0.107 & 0.209 & -0.019 & 0.174 & 0.045 & -0.008 & -9.1 & 109.1 \\
\hline 1990-1983 & 0.067 & -0.027 & -0.027 & -0.002 & 0.036 & 0.033 & 100.0 & 0.0 \\
\hline 1997-1990 & 0.309 & 0.265 & 0.181 & -0.045 & 0.152 & 0.022 & 68.1 & 31.9 \\
\hline 2001-1997 & 0.041 & 0.053 & 0.119 & 0.008 & 0.185 & 0.259 & 225.5 & -125.5 \\
\hline 2001-1980 & 0.323 & 0.566 & 0.019 & -0.045 & 0.724 & 0.133 & 3.3 & 96.7 \\
\hline
\end{tabular}

Source: Authors' estimates.

than the average, and resources were reshuffled towards more productive incumbents. Although entry exerted a positive effect, its contribution was low relative to that of reallocation across incumbents. Within-plant productivity growth was negative.

During the rest of 1980s aggregate TFP fell, driven by a negative contribution of within-plant productivity growth. Over the 1990s, however, TFP grew significantly with a positive contribution of the within-plant effect. Except for the slowdown experienced after 1997, total reallocation is large and positive.

Overall, reallocation captured almost all TFP growth in the long run $-96.7 \%$ during the 1980-2001 period-. This effect was mostly driven by the entry of new, more productive economic units. Compared to firms that were already producing in the early 1980s, entrants faced a more flexible economy, a superior technology, better access to credit markets, and a higher supply of skilled labor.

\section{CONCLUDing REMARKS}

Using Chilean manufacturing plants data for the 1980-2001 period, we have estimated micro level TFPs and found that reallocation is key for aggregate efficiency changes. The reshuffling of resources across incumbents, and especially the entry and exit process, accounted for almost all of total efficiency gains in Chile during the last two decades. Moreover, within-plant productivity growth contributes positively only during the 1990s, consistently with the existence of a lag between the implementation of major market oriented structural reforms -mostly undertaken during the late 1970s and early 1980s- and their complete effect on the economy. Once reforms were consolidated, unbounded within-plant efficiency gains driven by technology adoption and innovation occurred.

The policy implication is evident: exposing firms to the best practices -for instance through market oriented policies- is key to generate conditions 
that promote aggregate growth. On the opposite side, rigidities that block the natural process of birth, expansion, and death of plants, and the reallocation of resources among economic units, impede growth and limit development. Indeed, flexibility is key to growth.

\section{REFERENCES}

Alvarez, R. and R. López (2005a). "Exporting and Performance: Evidence from Chilean Plants." Canadian Journal of Economics, 38, 1384-1400.

Alvarez, R. and R. López (2005b). "Productivity Spillovers from Exporting through Vertical and Horizontal Linkages." Manuscript.

Barrett, G.F. and S.G. Donald (2003). "Consistent Tests for Stochastic Dominance." Econometrica, 71, 71-104.

Bartelsman, E. and M. Doms (2000). "Understanding Productivity: Lessons from Longitudinal Microdata." Journal of Economic Literature, 38, 569-94.

Basu, S. and J. Fernald (1995). "Aggregate Productivity and the Productivity of Aggregates." NBER Working Paper \# 5382.

Bergoeing, R., A. Hernando, and A. Repetto. (2005a). "Market Reforms and Efficiency Gains in Chile." Centro de Economía Aplicada, Universidad de Chile, mimeo.

Bergoeing, R., A. Hernando y A. Repetto (2005b). "Deflators and Capital Series for the ENIA: Technical Appendix.” Centro de Economía Aplicada, Universidad de Chile, mimeo.

Bergoeing, R., A. Micco, and A. Repetto. (2005). "Dissecting the Chilean Export Boom.” Manuscript, Centro de Economía Aplicada, Universidad de Chile.

Bergoeing, R., N. Loayza, and A. Repetto. (2004). "Slow Recoveries." Journal of Development Economics, 75, 473-506.

Comin, D., and S. Mulani. (2005). "Diverging Trends in Macro and Micro Volatility: Facts.” New York University, mimeo.

Chang, R., L. Kaltani, and N. Loayza. (2005). "Openness Can Be Good for Growth: The Role of Policy Complementarities.” World Bank Policy Research Working Paper 3763.

De Gregorio, J. (2004). "Economic Growth in Chile: Evidence, Source and Prospects." Documento de Trabajo \# 298, Banco Central de Chile.

Ericson, R. and A. Pakes. (1995). "Markov-Perfect Industry Dynamics: A Framework for Empirical Work." Review of Economic Studies, 62, 53-82.

Eslava M., A. Kugler, M. Kugler, and J. Haltiwanger (2004). "The Effects of Structural Reforms on Productivity and Profitability Enhancing Reallocation: Evidence from Colombia." Journal of Development Economics, 75, 333-371.

Foster, L., J.C. Haltiwanger, and C.J. Krizan (1998). "Aggregate Productivity Growth: Lessons from Microeconomic Evidence.” NBER Working Paper \# 6803.

Griliches, Z. and J. Mairesse (1995). "Production Functions: The Search for Identification." NBER Working Paper \# 5067.

Hopenhayn, H. and R. Rogerson (1993). "Job Turnover and Policy Evaluation: A General Equilibrium Analysis," Journal of Political Economy, University of Chicago Press, vol. 101(5), pages 915-938.

Kehoe, T. and E. Prescott. (2002). "Great Depressions of the Twentieth Century," Review of Economic Dynamics, 5, 1-18. 
Levinsohn, J. and A. Petrin. (2003). "Estimating Production Functions Using Inputs to Control for Unobservables." Review of Economic Studies, 70, 317-341.

Melitz, M. (2003). "The Impact of Trade on Intraindustry Reallocations and Aggregate Industry Productivity." Econometrica, 71.

Micco, A. (1995). "Creación, Destrucción y Reasignación de Empleos en Chile.” M.A. Thesis, Universidad de Chile.

Ministerio de Hacienda (2004). "Acta de Resultados del Comité Consultivo del PIB Tendencial", Dirección de Presupuestos, agosto.

Olley, S. and A. Pakes. (1996). "The Dynamics of Productivity in the Telecommunication Equipment Industry.” Econometrica, 64, 1263-1298.

Pakes, A. (1994). "Dynamic Structural Models, Problems and Prospects: Mixed Continuous Discrete Controls and Markets Imperfections." In Sims, C. (Ed.), Advances in Econometrics, Sixth World Congress Volume II, 171259, New York, Cambridge.

Parente, S. and E. Prescott. (2000). Barriers to Riches, The MIT Press.

Prescott, E. (2002). "Prosperity and Depression: 2002 Richard T. Ely Lecture." American Economic Review, Papers and Proceedings, 92, 1-15.

Pavcnik, N. (2002). "Trade Liberalization, Exit, and Productivity Improvements: Evidence from Chilean Plants." The Review of Economic Statistics, 69, 215-242.

Solimano A. and R. Soto. (2006). "Economic Growth in Latin America in the Late Twentieth Century: Evidence and Interpretation", in Vanishing Growth in Latin America, A. Solimano (ed.), Edward Elgar Publishers.

Syverson, C. (2004). "Market Structure and Productivity: A Concrete Example." Journal of Political Economy, 112, 1181-1222. 
